\title{
Peptidoglycan and Bacterial DNA Induce Inflammation and Coagulation Markers in Synergy
}

\author{
Marie-Claude Amoureux, ${ }^{1}$ Nandani Rajapakse, ${ }^{1}$ Lazlo Stipkovits, ${ }^{2}$ and Susan Szathmary ${ }^{1,2}$ \\ ${ }^{1}$ Clarigen Inc, 5922 Farnsworth Court, Carlsbad, CA 92008, USA \\ ${ }^{2}$ Hungarian Academy of Sciences, Veterinary Medical Research Institute, 1143 Budapest, Hungaria krt 21, Hungary
}

Received 30 November 2004; accepted 15 December 2004

\begin{abstract}
Bacterial compounds signal the presence of foreign pathogens in the innate immune system. These microbial components are key players in infectious diseases and implicate toll-like receptors in the activation of inflammation and coagulation. Nevertheless, the existence of a synergistic relationship between peptidoglycan and bacterial DNA on these two physiological responses has not been investigated. The present study reports new findings on the regulation of tumor necrosis factor alpha and tissue factor in peripheral blood mononuclear cells by peptidoglycan and bacterial DNA. These were found to induce tumor necrosis factor alpha and tissue factor simultaneously and in a synergistic manner. These findings provide a new proinflammatory and procoagulant mechanism likely to play a role in sepsis pathogenesis.
\end{abstract}

\section{INTRODUCTION}

Toll-like receptors (TLRs) allow the innate immune system to distinctively identify foreign pathogenic molecules, but, if overstimulated, can become mediators of sepsis. Lipopolysaccharide (LPS) is known to play a critical role in sepsis. However, as our understanding of Gram-negative and Gram-positive infections expands, other TLRs ligands, including lipoteichoic acid (LTA), peptidoglycan (PepG), lipoproteins, flagellin, and CpG-rich unmethylated bacterial DNA (bactDNA), have been recognized to be involved [1]. PepG, a main component of bacterial cell walls, can activate leukocytes, generate proinflammatory cytokines such as tumor necrosis factor alpha (TNF- $\alpha$ ), interleukin-1 (IL-1), IL-6, and cause systemic inflammatory response syndrome $[2,3,4]$. PepG was also shown to mediate platelet aggregation in Staphylococcus aureus septicemia [5], induce tissue factor (TF) in monocytes, and display procoagulant activity [6]. BactDNA induces the production of TNF- $\alpha$ in macrophages in vitro. BactDNA leads to septic shock and death in sensitive mice [7]. Because of the cooperation between TLRs and the common denominators downstream of TLR activation, synergistic effects between microbial pathogenic compounds have been observed. Whereas LTA can cause only moderate hypotension, PepG coadminis-

Correspondence and reprint requests to Marie-Claude Amoureux, Clarigen Inc, 5922 Farnsworth Court, Carlsbad, CA 92008, USA; mcamoureux@earthlink.net tered with LTA induces multiorgan dysfunction and death in rats $[8,9]$. BactDNA also increases the toxicity of LPS in mice [10]. However, synergistic effects between bactDNA and PepG have not been reported. Moreover, although IL-1, induced by bacterial toxins including bactDNA, has been shown to induce TF in endothelial cells $[11,12]$, the effect of bactDNA on the regulation of TF in monocytes has not been described.

The goal of this study was to investigate the effect of bactDNA and PepG, on the induction of a marker of inflammation, TNF- $\alpha$, in human peripheral blood mononuclear cells (PBMC), and of a coagulation marker, $\mathrm{TF}$, in monocytes, and to test the hypothesis that bactDNA and PepG can exert synergistic effects.

\section{MATERIALS AND METHODS}

Peripheral blood mononuclear cells were prepared by Ficoll separation of peripheral blood from healthy volunteers as previously described [13]. Mononuclear cells were plated at a density of $10^{6}$ cells $/ \mathrm{mL}$ in $1.5 \mathrm{~mL}$ RPMI 1640 (Irvine Scientific, Santa Ana, Calif), supplemented with $100 \mathrm{U} / \mathrm{mL}$ penicillin/streptomicin, $2 \mathrm{mM}$ glutamine, and $3 \%$ fetal calf serum, and treated with PepG (Sigma, St Louis, Mich), bactDNA (KM Biomedicals, Aurora, Ohio; LPS $<0.2 \mathrm{EU} / \mathrm{mL}$ measured by the limulus amebocyte lysate assay [13]), or both. TNF- $\alpha$ was measured by ELISA from the culture supernatant after 5-hour incubation and elimination of nonadherent cells. The TNF- $\alpha$ ELISA kit from Cell Sciences (Norwood, Mass) was used. 


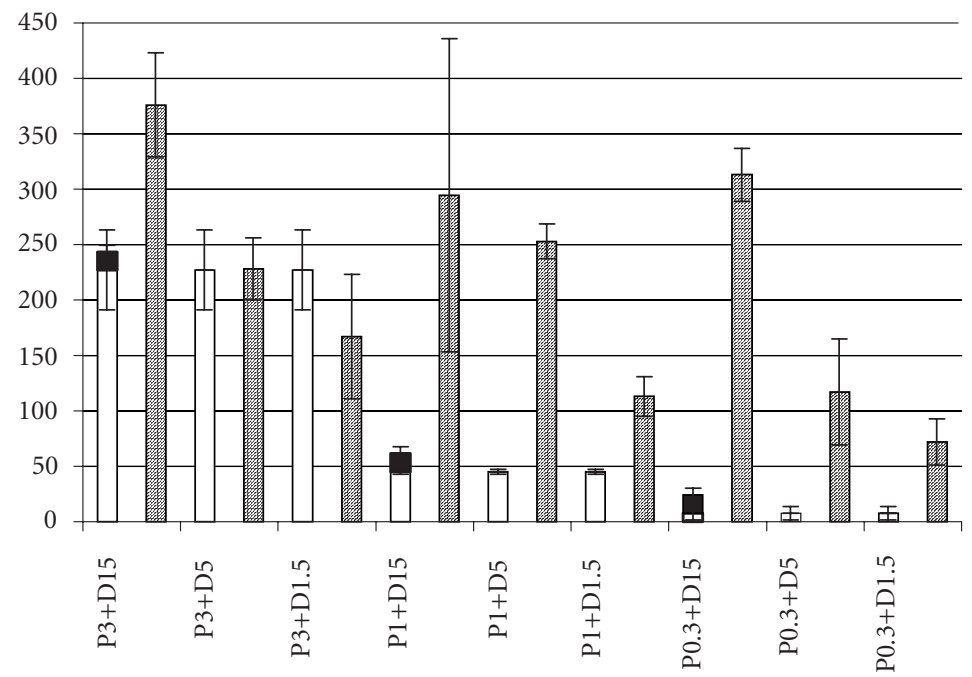

(a)

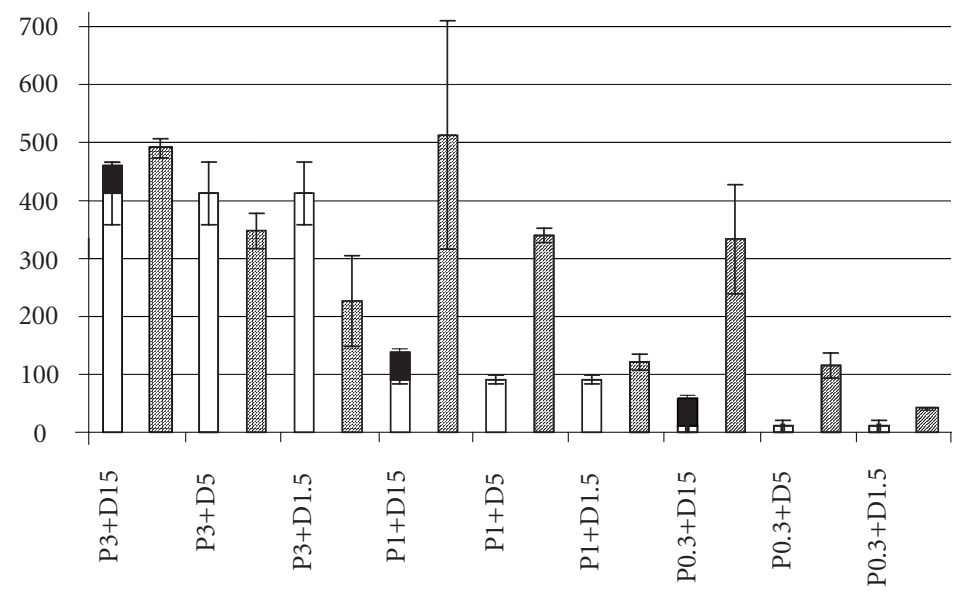

(b)

Figure 1. TNF- $\alpha$ secreted by PBMC (a) and monocytic TF (b) after treatment with PepG (white bar), bactDNA (black bar), or both simultaneously at the same concentration as when added alone (hatched bar). The numbers following $\mathrm{P}$ and $\mathrm{D}$ indicate the concentrations of PepG and bactDNA in $\mu \mathrm{g} / \mathrm{mL}$, respectively. $P<.05$ for TNF- $\alpha$ and TF, when comparisons were made between the sum of the effects of PepG ( 1 or $0.3 \mu \mathrm{g} / \mathrm{mL})$ and bactDNA alone at all concentrations tested, and when PepG and bactDNA were added together; Student $t$ test $(n=4)$.

The coefficient of variation for the TNF- $\alpha$ ELISA was less than $8.9 \%$ for duplicate measurements of a single culture. The lowest detection limit was $10 \mathrm{pg} / \mathrm{mL}$.

Tissue factor in monocytes was evaluated from the corresponding PBMC cultures used for TNF- $\alpha$ analysis. After 5 hours of treatment, TF was extracted from the adherent cells with phosphate buffered saline containing $0.1 \%$ Triton X100 as recommended by the manufacturer for subsequent TF ELISA. The Imubind kit from American Diagnostica (Greenwich, Conn) was used. The coefficient of variation for the TF ELISA was less than $9.7 \%$ for duplicate measurements of a single culture. The sensitivity of the assay was $10 \mathrm{pg} / \mathrm{mL}$.

Numerical data were analyzed by using the Student $t$ test. A $P$ value less than .05 was considered statistically significant.

\section{RESULTS}

Induction of TNF- $\alpha$ secretion in PBMC cultures was used as an in vitro assay for the determination of an inflammatory reaction. TF is an initiator of coagulation and was used as an indicator of a procoagulant reaction. There was no detectable TNF- $\alpha$ or TF in untreated cells, and no significant difference in the amount of proteins extracted from monocytes between treatment conditions was measured (not shown). Both PepG and bactDNA applied individually to PBMC were able to induce TNF- $\alpha$ and TF in a dose-response fashion (Figure 1). In presence of high concentration of PepG $(3 \mu \mathrm{g} / \mathrm{mL})$, adding bactDNA did not generate significantly more TNF- $\alpha$ or TF, except at $15 \mu \mathrm{g} / \mathrm{mL}$ bactDNA for TNF- $\alpha$. However, when lower concentrations of PepG $(1 \mu \mathrm{g} / \mathrm{mL}$ or $0.3 \mu \mathrm{g} / \mathrm{mL})$ were used, 
treatment with bactDNA and PepG simultaneously generated more TNF- $\alpha$ and TF than when adding the effect of the two compounds used separately $(P<.05)$ (Figure 1). The induction of TNF- $\alpha$ and TF was up to 15and 10-fold higher, respectively, when PepG and bactDNA were present in conjunction, than when adding the effect of the two molecules alone. These results indicate that PepG and bactDNA act in synergy, even when bactDNA alone does not induce detectable TNF- $\alpha$ or TF by itself.

\section{DISCUSSION}

The present results demonstrate the concomitant induction of TNF- $\alpha$ and TF by PepG and bactDNA in PBMC, and a synergistic effect between the two molecules. Although the molecular mechanism for this synergy remains to be elucidated, it could involve direct effects on common downstream signaling pathways, or indirect effects mediated by secreted compounds following PepG or bactDNA action.

The increase in TF expression on monocytes by bactDNA is a new finding and may have significance in disseminated intravascular coagulation. Indeed, an increase in TF elicited by PepG and/or bactDNA could have local as well as systemic effects, as TF has been shown to be present on circulating monocytes [14]. TNF- $\alpha$ is an important early mediator of host responses to pyrogens and is the only endogenous mediator capable of triggering the entire spectrum of metabolic, hemodynamic, tissue, and cytokine cascade responses of septic shock. These results are also significant in as much as the crosstalk between inflammation and coagulation is an aspect to consider in the quest of an effective therapy for septic shock. The synergistic effects of bactDNA and PepG also have implications for the pathogenesis of sepsis, where each molecule, although present at low concentrations in vivo, is likely to amplify the effect of another one, as hypothesized previously [15].

\section{REFERENCES}

[1] Akira S, Hemmi H. Recognition of pathogenassociated molecular patterns by TLR family. Immunol Lett. 2003;85(2):85-95.

[2] Wang ZM, Liu C, Dziarski R. Chemokines are the main proinflammatory mediators in human monocytes activated by Staphylococcus aureus, peptidoglycan, and endotoxin. J Biol Chem. 2000;275(27):20260-20267.

[3] Mattsson E, Verhage L, Rollof J, Fleer A, Verhoef J, van Dijk H. Peptidoglycan and teichoic acid from Staphylococcus epidermidis stimulate human monocytes to release tumour necrosis factoralpha, interleukin-1 beta and interleukin-6. FEMS Immunol Med Microbiol. 1993;7(3):281-287.
[4] Heumann D, Barras C, Severin A, Glauser MP, Tomasz A. Gram-positive cell walls stimulate synthesis of tumor necrosis factor alpha and interleukin- 6 by human monocytes. Infect Immun . 1994;62(7):2715-2721.

[5] Kessler CM, Nussbaum E, Tuazon CU. Disseminated intravascular coagulation associated with Staphylococcus aureus septicemia is mediated by peptidoglycan-induced platelet aggregation. J Infect Dis. 1991;164(1):101-107.

[6] Mattsson E, Herwald H, Bjorck L, Egesten A. Peptidoglycan from Staphylococcus aureus induces tissue factor expression and procoagulant activity in human monocytes. Infect Immun. 2002;70(6):30333039.

[7] Sparwasser T, Miethke T, Lipford G, et al. Macrophages sense pathogens via DNA motifs: induction of tumor necrosis factor-alpha-mediated shock. Eur J Immunol. 1997;27(7):1671-1679.

[8] De Kimpe SJ, Kengatharan M, Thiemermann C, Vane JR. The cell wall components peptidoglycan and lipoteichoic acid from Staphylococcus aureus act in synergy to cause shock and multiple organ failure. Proc Natl Acad Sci USA. 1995;92(22):10359-10363.

[9] Kengatharan KM, De Kimpe S, Robson C, Foster SJ, Thiemermann C. Mechanism of gram-positive shock: identification of peptidoglycan and lipoteichoic acid moieties essential in the induction of nitric oxide synthase, shock, and multiple organ failure. J Exp Med. 1998;188(2):305-315.

[10] Cowdery JS, Chace JH, Yi AK, Krieg AM. Bacterial DNA induces NK cells to produce IFN-gamma in vivo and increases the toxicity of lipopolysaccharides. J Immunol. 1996;156(12):4570-4575.

[11] Bevilacqua MP, Pober JS, Majeau GR, Cotran RS, Gimbrone MA Jr. Interleukin 1 (IL-1) induces biosynthesis and cell surface expression of procoagulant activity in human vascular endothelial cells. $J$ Exp Med. 1984;160(2):618-623.

[12] Nawroth PP, Handley DA, Esmon CT, Stern DM. Interleukin 1 induces endothelial cell procoagulant while suppressing cell-surface anticoagulant activity. Proc Natl Acad Sci USA. 1986;83(10):3460-3464.

[13] Amoureux MC, Hegyi E, Le D, Grandics P, Tong $\mathrm{H}$, Szathmary S. A new method for removing endotoxin from plasma using hemocompatible affinity chromatography technology, applicable for extracorporeal treatment of septic patients. J Endotoxin Res. 2004;10(2):85-95.

[14] Giesen PL, Nemerson Y. Tissue factor on the loose. Semin Thromb Hemost. 2000;26(4):379-384.

[15] Horn DL, Morrison DC, Opal SM, Silverstein R, Visvanathan K, Zabriskie JB. What are the microbial components implicated in the pathogenesis of sepsis? Report on a symposium. Clin Infect Dis. 2000;31(4):851-858. 


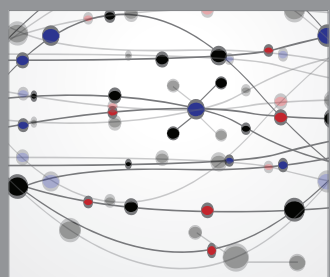

The Scientific World Journal
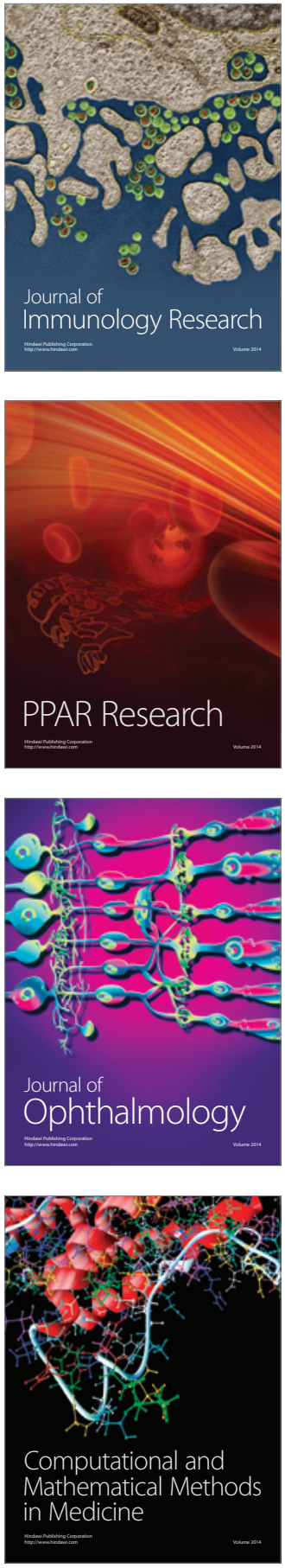

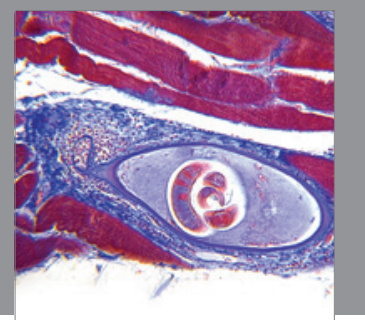

Gastroenterology

Research and Practice
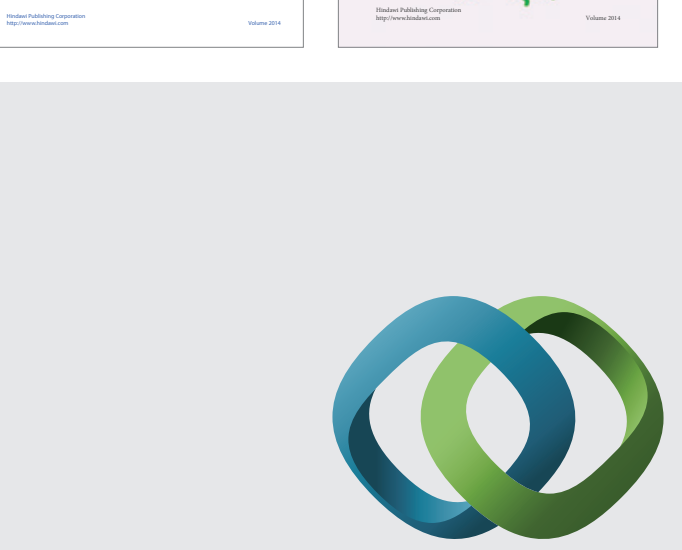

\section{Hindawi}

Submit your manuscripts at

http://www.hindawi.com
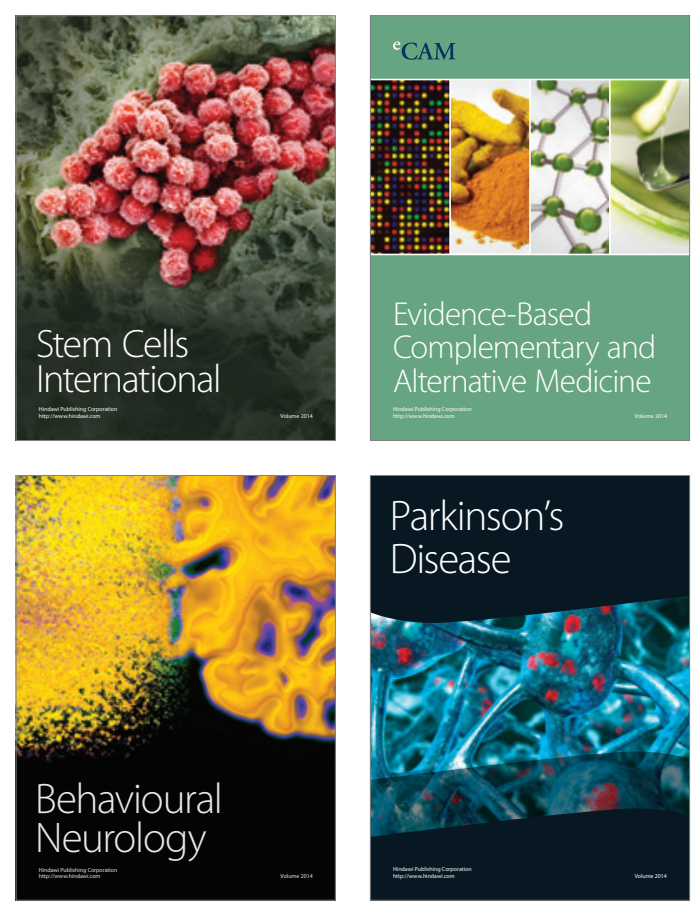

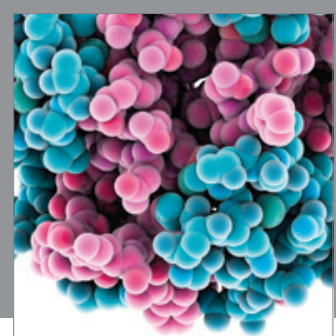

Journal of
Diabetes Research

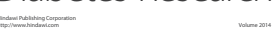

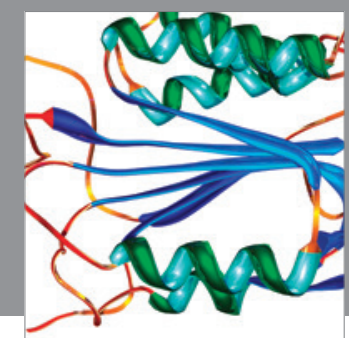

Disease Markers
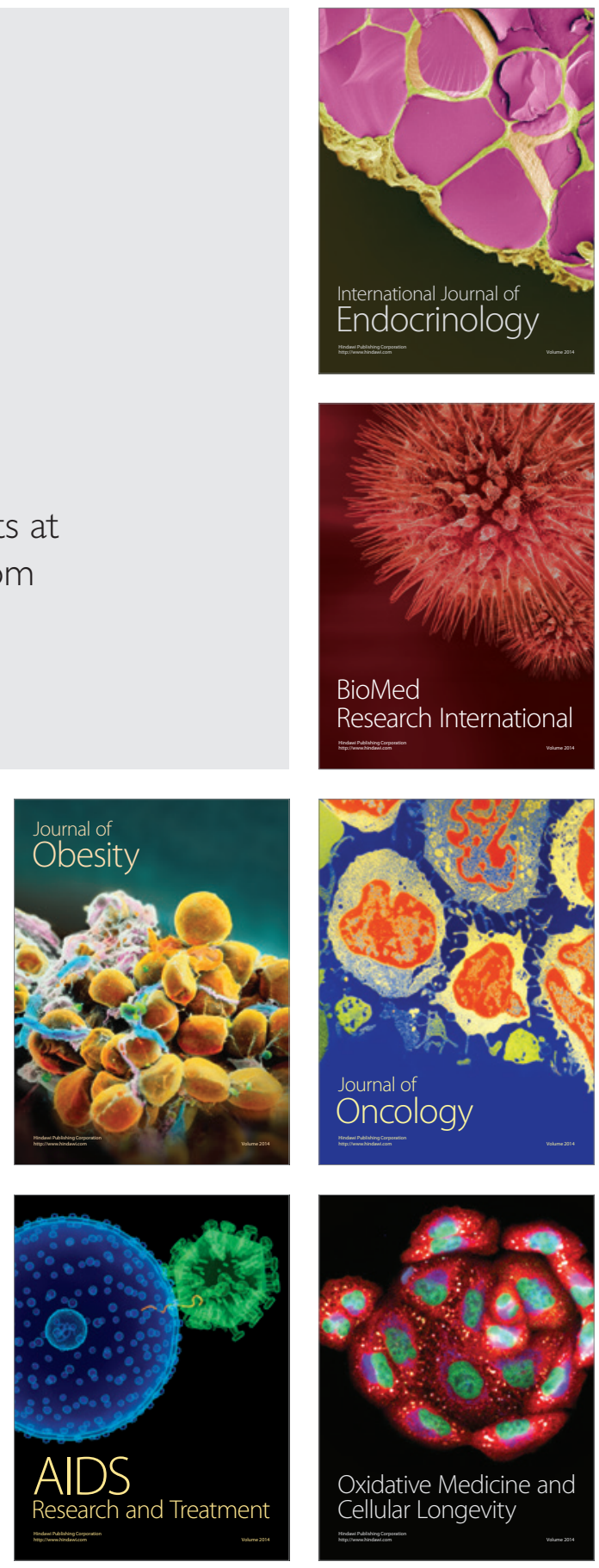